\title{
STRATEGIES OF PROTECTION OF INTELLECTUAL PROPERTY AS AN INTANGIBLE REGULATORY ASSET OF AN ORGANISATION
}

\author{
Aldona Małgorzata Dereń*
}

\begin{abstract}
In the article the submitted a special kind of intangible resource regulatory of intellectual property in organization. One of the features of intellectual property is the ability to protection. .In the process of the management of intellectual property this feature determines the definition and implementation of strategies to protect these resources. Strategy for the protection of intellectual property must be subordinated to organization. The article discusses the strategy of explicit (institutional) intellectual property protection strategy implicit (non-institutional) and a strategy based on the sale of its own intellectual resources and / or obtaining external resources. Selected and discussed strategies that fully demonstrate the ability to protect as a resource asset of intellectual property were the subject of research conducted in a group of Polish companies from the Lower Silesia region. The results of this study are presented in this article.
\end{abstract}

Background. In contemporary organizations, intellectual resources are a key element of strategic thinking, which should take three directions: creation, maintenance and protection of these resources. Therefore, it is necessary to formulate and implement a specific strategy for securing intellectual property resources. This strategy should be part of a competitive organizational development strategy.

Research aims. The aim of the article is to present the types of strategies for securing intellectual property in enterprises in the Lower Silesia region in Poland.

Methodology. The basis of the analysis presented in this article was the questionnaire survey conducted in the group of 137 entrepreneurs from the Lower Silesia region. Survey questions focused on issues related to the knowledge of the types of intellectual property protection strategies and their practical implementation.

Key findings. The analysis allowed to distinguish two types of strategies for securing intellectual property: institutional strategies (patent, protective rights, etc.) and non-institutional strategies (know-how, company secrets). The vast majority of surveyed entrepreneurs apply institutional strategies to protect intellectual property despite complex formal procedures and significant costs of protection.

Keywords: organization, resources, intellectual property protection.

\footnotetext{
* Wrocław University of Science and Technology, E-mail: aldona.deren@pwr.edu.pl
} 


\section{INTRODUCTION}

The changes taking place on the contemporary market, which is characterised by turbulence, dynamism, complexity and emergence (Stańczyk-Hugiet, 2013, p. 24), require searching for new resources that will allow organisations to develop through innovations. This development is determined not only by new technologies, but also by new methods, strategies and models of organisation management that more commonly utilise intangible assets. The need to protect intellectual property generated by the employees and intellectual assets collected in an organisation determines its development and the process of creating competitive advantage. Not all sectors are subjected to a strong pressure from this type of assets, but some of them (computer science, telecommunications, biotechnology) are absolutely dependent upon intellectual assets.

The purpose of the article is to characterise the particular type of intangible regulatory assets, namely intellectual property in an organisation. One of the asset features of intellectual property is its protection ability. In the intellectual property management process, this feature determines how the protection strategy of these resources is formulated and implemented. The selected and discussed strategies of explicit (institutional) intellectual property protection, implicit (non-institutional) strategies and strategies based on sales of own intellectual assets and/or acquisition of external assets best show the ability to protect intellectual property assets, and in practice constitute a tool for creating competitive advantage of the organisation.

\section{TYPES OF ASSETS IN AN ORGANISATION}

The literature developed relatively stable views on the main types of assets, though particular authors classify them differently. One of such classifications is the division of assets into three main groups: tangible assets, human assets and intangible assets.

Tangible assets cover two categories: natural resources and capital resources. Natural resources are the gift of nature and, as elements of nature, perform two basic functions: form the living environment of humans and, at the same time, constitute the factors of production 
processes. These resources have various classifications. Some of them are non-exhaustive (for instance, geographic location and space), others are exhaustive, and the latter include renewable and non-renewable resources (Woś, 1995, p. 11).

Capital resources include physical resources (for instance buildings, devices, machines) and financial resources of the organisation, being in its possession and possible to obtain (Pierścionek, 1996, p.119). The most important and common trait of these resources is their source character and limited availability. In addition, these resources are not unique, which means that every organisation can have them. In practice, each organisation should have some capital resources to be able to operate. Therefore, it can be assumed that all businesses may have similar (in terms of type) capital resources. The aforementioned characteristics of tangible assets, especially their progressively limited availability, have contributed to the shift in significance of these assets in the context of the adopted development paradigm in the global system and in business strategies of organisations, due to the continuously growing human needs and the rapidly shrinking material resources, as well as the alarming global population growth. The new paradigm of Knowledge-Based Economy (KBE) recognises human and intangible assets as the main organisation assets, as they determine the uniqueness and distinctness of the organisation, and condition its creation of competitive advantage. According to R.L. Parr and G.V. Smith intangible assets are now recognized as the important competitive factor that has a significant impact on the market value of enterprises (Parr \& Smith, 2010, p. 4).

Human assets are the features of employees (physical and mental, as well as the employee's character, health and the related vitality) and their competencies (skills, knowledge and experience). As compared to other assets, human assets continuously gain importance, though the approach to the features most emphasised and most desired by companies changes. Contemporary organisations are looking for creative and talented employees, ready for changes, willing to take risks and responsibilities, self-managing, thinking and constructively critical. Innovative organisations form creative teams, where more and more decisions are made by employees, and delegation of decision-making rights to lower levels is an organisational rule (Toffler \& Toffler, 1999, p. 101).

Growth in the importance of employee creativity necessitates changes in the organisation and in the management style of organisations. 
The traditional concepts of business activity lose their significance to be replaced with teams consisting of employees with knowledge that allows them to notice the interrelations and structures inside and outside the organisation. The skill level is also connected with the need for self-fulfilment and tolerance, and with a different viewpoint than in the past. Such employees cannot be freely replaced, since their individuality determines their value (Toffler \& Toffler, 1997, p. 87).

As regards intangible assets, management sciences propose various classification configurations. For example, according to R. Hall, intangible assets can be divided into two categories: assets and skills (Hall, 1992, p. 136). The latter are defined as the capability to use the resources (Sitek, 1997, p. 758), resulting from knowledge carried and developed by the human capital of the organisation. They are typical of a particular organisation or industry, which results from the complex of historical interactions between resources. Skills can be in an abstract way considered intermediate goods generated by the organisation in order to more effectively manage the resources. Other division criteria of intangible assets can also be used, distinguishing:

- assets dependent or independent from people;

- protected (regulatory) assets - contracts, licenses, business secrets, intellectual property rights;

- assets not protected by the law (position - reputation, contacts, databases, information);

- functional assets (knowledge and skills of employees and suppliers); cultural assets (organisational culture and capacity to learn) (Hall, 1992, p. 140).

The literature indicates several significant features differentiating intangible assets from tangible assets (Obłój, 2001, pp. 222-223). The first one is the possibility of using intangible assets in many places, contrary to tangible assets, which are used in the specific place where they are located. The second typical feature of intangible assets is the period of their development, which sometimes takes many years (e.g. a new technological solution is developed and tested even for several years, a product brand is shaped for years, etc.). The third feature of intangible assets is their indestructibility during their use.

Other significant differences between tangible and intangible assets that demonstrate the importance of the latter concern (Mikuła et al., 2002, p. 30; Głuszek, 2004, p. 65): their place in the conventional 
accounting systems - tangible assets are visible, quantifiable balance sheet components, while intangible assets are usually immeasurable; the possibility of gathering - tangible assets can be collected and stored, while intangible assets are of dynamic nature and may disappear when not in use or dramatically lose their value; legal protection through ownership - tangible assets are covered by full and strict protection that is quite easy to enforce, while intangible assets are covered by special kind of protection, which is often difficult to enforce in practice.

\section{INTELLECTUAL PROPERTY AS AN INTANGIBLE REGULATORY ASSET OF AN ORGANISATION}

Intellectual property covers all products of the human mind, results of creative work, talent, imagination, creativity and invention, as well as certain outlays (time, funds and physical capital, current state of technology). When they are created in an organisation, they are used as intangible assets in the process of creation of subsequent goods and services. Roger D. Blair and Thomas F. Cotter point out that intellectual property distinguishes it from its economic value and is protected by law (Blair \& Cotter, 2005, pp. 1-2). If knowledge resources are the subject of intellectual property rights, it is possible to reap the financial benefits of dissemination and use of these resources - sales, transfers, commercialization. In this case, we also deal with legal protection against their unauthorized use for commercial purposes (Bainbridge, 2009, pp. 22-30; Barrett, 2008, pp. 1-4; May, 2007, pp. 4-8).

The uniqueness of the products of creative work of individuals, and, at the same time, their economic/business/development significance, determines the framework of their protection, demonstrated by the legal monopoly that guarantees exclusivity (monopoly) with regard to professional and gainful use of these assets. Patents or protection rights granted by the Patent Office guarantee this exclusivity. Another way to protect intellectual assets is the know-how, namely protection inside the organisation, which treats these resources as confidential, assigning them the "trade secret" clause.

The monopoly of intellectual property is determined by the so-called intellectual property rights that emphasise one of the asset features of 
intellectual property, namely the ability to protect (Dereń, 2015a, pp. 65-79). Human achievements in the area of intangible assets are the derivative of the amount of labour and funds, as well as creativity and talent in taking the current state of knowledge into account. Combined with the tangible potential of the organisation, they determine its position on the market. Maintenance of intellectual assets, as well as the need for their continuous development are expensive, hence incurring of high expenses is justified by waiting for these assets to generate higher production efficiency, increase in sales, and, as a result, to increase income. In this situation, it is necessary to protect intellectual assets and fully utilise the priority of introduction of the new product prepared on its basis to the market. Lack of such protection of intellectual property may result in the products being quickly imitated by competitive entities and in the strategic plans of the organisation being thwarted, or may even generate substantial losses. The ability to protect, as an asset feature of intellectual property, determines the process of intellectual property management in an organisation in the operational aspect.

The very fact of having intellectual assets and launching new products developed on the basis of these assets is certainly very important, however, the crucial element of building a strong competitive position is to protect these assets that were used in the process of creating new products. This notion should be understood as a set of actions used for retaining value within the organisation, both in terms of current management, as well as the organisation's strategy.

On the basis of the subject literature and the research of the predecessors, it can be stated that the decision to apply appropriate tools for protection of intellectual property depends on many factors, among others, on the type of possessed resources, the industry the organisation operates in, the amount of costs incurred on protection as compared to costs of losing the market position built as a result of this resources, and the adopted strategy. 


\section{INTELLECTUAL PROPERTY PROTECTION STRATEGIES IN REGULATORY ASSETS MANAGEMENT IN AN ORGANISATION}

Intangible assets, covered by the scope of the notion of intellectual property, are resources that, as any other, are covered by the management processes. Intellectual property management is a set of mutually related activities focused on acquisition, maintenance and exploration of intangible goods that may be subject to protection, as well as on their conversion to assets of intellectual value. Intellectual property management components should include actions covering, among others, accurate identification of creative (inventive) capabilities in the organisation and their transformation into forms of intellectual property; "mapping" of all intellectual property assets contained in products and services from the point of view of the value that each of them may generate for the organisation, of profits that each of them may generate, as well as preparation of a proper strategy of protection of intellectual property assets. This strategy should be associated with competition strategies, strategies of building assets (including intellectual assets), marketing strategies, brand strategies, strategies of launching new products, creating the image of the organisation, technology and product (Trzmielak \& Byczko, 2010, p. 88). Such a holistic approach allows for making actions protecting intellectual property assets dependent upon organisational objectives, which in the process of intellectual property management means selection and adoption of the strategy of explicit (institutional) protection of intellectual property, the strategy of implicit (non-institutional) protection or the strategy based on sales of own intellectual assets and/or acquisition of external assets.

Protection of intellectual property may be based, for instance, on patents, utility models, trademarks submitted to the patent office, registered, protected by the national and international law (Allen, 2010, pp. 85-109). In this case, intellectual property protection is explicit and everyone may obtain information on the object of protection. The explicit strategy means that the company discloses the new solution, its description, drawings used in order to apply for protection - usually patent protection. The explicit strategy is based on the adopted regulations of industrial property, and its unquestionable advantage 
is the smaller risk of violations of industrial property and the greater possibility to enforce exclusive rights e.g. to a patent, or protective rights to trademarks. The effectiveness of this strategy determines the strong legal protection system adopted in the legislation of a given country, as well as the time, in which it is important to suspend, for example, production, sales of the copied technologies and products.

The actions undertaken in the intellectual property management process, aimed at development and selection of the explicit strategy of intellectual property protection, require taking account of the geographical constraints involved in patent protection. As noticed by D. Trzmielak and Sz. Byczko, markets can be expanded for one year after obtaining the patent protection. Lack of patent protection on markets containing prospective customers of the organisation and companies with suitable resources to imitate or copy the technology and the new products may impede the organisation's operation (Allen, 2010, p. 87). Losses depend on how quickly the technologies and new solutions of the company are imitated and copied. However, imitation may be quicker if the organisation has patent protection on a different market than if it has no patent protection on the market, where the intellectual property is violated. The object and scope of the patent are made available to the public. Every organisation operating on the market analyses the already existing inventions on the basis of intellectual resources. Review of patent databases of patent offices is one of the first activities when searching for alternative technologies or technologies to imitate. Protection on one market may result in the technology and product being copied on other markets. Therefore, it is important to first analyse the target markets, resources of other entities (also in terms of breaching the rights of other entities) that can be used to manufacture similar, alternative technologies and products (Allen, 2010, p. 87). Only then should the organisation consider whether to protect intellectual property explicitly, where to protect it, and whether to limit itself, for instance, to building a strong position, technology or a new product through other market actions.

Patent protection also involves costs for the organisation. Therefore, the explicit strategy should clearly comply with the development plans of the organisation, a given technology or the new product. This way, the organisation can prepare for commercialisation activities in the target markets and for expenses associated with the protection of intellectual property (Allen, 2010, p. 87). 
Adoption of patents as a form of protection of intellectual assets in the intellectual property management process is tantamount to the need to select a specific strategy. The types of these strategies are presented in Table 1.

Table 1. Types of patent strategies

\begin{tabular}{|c|c|}
\hline Strategy & Characteristics \\
\hline "Ad hoc" patent strategy & $\begin{array}{l}\text { This strategy is a result of ad hoc efforts and small funds. One } \\
\text { or more patents may be used for protection of the innovation } \\
\text { through a specific program. There are many possibilities to } \\
\text { search for them and their costs are low. }\end{array}$ \\
\hline "Blocking" & $\begin{array}{l}\text { These strategies are used when the organisation intends to use } \\
\text { the patents, but they are applied as a real alternative against } \\
\text { its competitors. }\end{array}$ \\
\hline $\begin{array}{l}\text { "Shotgun" strategy / } \\
\text { patent portfolio strategy }\end{array}$ & $\begin{array}{l}\text { According to this strategy, the patent holder seeks to have as } \\
\text { many patents as possible in a specific area of technology. This } \\
\text { approach is supposed to create an impression that the area of } \\
\text { technology is so saturated with patents that it is almost impos- } \\
\text { sible for the competition to patent anything or to avoid violating } \\
\text { one or many binding patents. However, while providing optimal } \\
\text { protection, this method may be costly and not appropriate for } \\
\text { small and medium enterprises, which due to their nature have } \\
\text { lower budgets on development and research. Therefore, it is ex- } \\
\text { tremely important for small and medium enterprises to create } \\
\text { such profitable management of the patent asset of intellectual } \\
\text { property, which will ensure a commercially realistic balance } \\
\text { between the approach of "putting all eggs in one basket" and } \\
\text { the "patent anything and everything" approach. }\end{array}$ \\
\hline $\begin{array}{l}\text { "Market coverage" } \\
\text { strategy }\end{array}$ & $\begin{array}{l}\text { In this case, the efforts are focused on transforming the area } \\
\text { into a jungle or a mine field of patents, e.g. by more or less } \\
\text { systematically flooding each step of the manufacturing process } \\
\text { with new patents. This strategy may be applied in newly } \\
\text { arising technologies, when the success of the directions of de- } \\
\text { velopment and research is highly uncertain, or in situations of } \\
\text { uncertainty concerning the economic importance of the scope of } \\
\text { the patent protection. }\end{array}$ \\
\hline "Fence" strategy & $\begin{array}{l}\text { Some organisations apply for patents not only for their main } \\
\text { technologies, but also covering the growing progress, so as } \\
\text { to create a certain "fence" to keep the competition away. The } \\
\text { "fence" strategy usually requires submission of numerous pat- } \\
\text { ent applications for each patent and product issued by the com- } \\
\text { petition, in order to patent improvements in the competition's } \\
\text { technology and reduce its future mobility. }\end{array}$ \\
\hline "Enclosure" & $\begin{array}{l}\text { In this case, the central patent, especially if it is strategic for } \\
\text { the company, may be confined or surrounded by other patents } \\
\text { that are less important, but together effectively block the com- } \\
\text { mercial use of the central patent, even after its expiration. }\end{array}$ \\
\hline
\end{tabular}




\begin{tabular}{|l|l|}
\hline "Prestige" strategy & $\begin{array}{l}\text { Some companies believe that prestige and leadership accom- } \\
\text { panying the patent may help their operations and constitute } \\
\text { the driving force for this strategy. Academic and research } \\
\text { institutions are also known to submit patent applications to } \\
\text { achieve recognition in their research work. Small companies } \\
\text { may also seek patent protection to impress potential investors } \\
\text { and promote the originality of their technology. }\end{array}$ \\
\hline "Scare-crow" strategy & $\begin{array}{l}\text { The patent holder may not intend to claim his rights, and in- } \\
\text { stead he may monitor whether the competition stays away from } \\
\text { the protected area. In this case, the patent works as a "scare- } \\
\text { crow", holding the competitors away from the holder's business } \\
\text { activity. This strategy is more often encountered in industries, } \\
\text { where large-scale submission of patents and frequent patent } \\
\text { disputes do not occur. Specialised companies will always be } \\
\text { more prone to looking for methods of creating around the patent } \\
\text { than less specialised ones, which will rather keep at bay than } \\
\text { invest in costly procedures. }\end{array}$ \\
\hline
\end{tabular}

Source: prepared by the author on the basis of: InnoSupport: support for innovations in smalland medium-sized enterprises, http://www.pl.gov.pl/innosupport; http://kramarz. pl/?p=/pl/publikacje/portfel_patentowy; Bąk \& Kulawczuk, 2009.

The issue of patenting and selection of a given strategy was examined in the survey conducted among enterprises operating in the region of Lower Silesia. Information was collected by means of a questionnaire, which constituted the basis for analysis of intellectual property assets as determinants of innovative potential (Dereń, 2015b, pp. 1-38). From the point of view of the presented topic of this article, the qualitative analysis covered 137 business entities in the context of the use of intellectual property assets and tools for their protection. The surveyed entities were selected using the random sampling method, and the main criterion for selection was the conduct of innovative business activities. The studied companies were dominated by the SME sector, which covered $15 \%$ of microenterprises employing up to 10 employees, $33 \%$ of small companies employing up to 50 employees, and $31 \%$ of medium-sized companies (50-250 employees). Large entities (250-500 employees) constituted 7\%, while enterprises employing more than 500 employees $14 \%$. Nearly $50 \%$ of respondents limited their operations to the analysed region, $40 \%$ operate on the domestic market, and $10 \%$ on the international market. Half of the respondents provide services, the remaining ones conduct operations with regard to production and trade. On the basis of the obtained information, it can be stated that, for the examined companies, intellectual property assets, their conscious shaping, gathering, as well as their protection are not a matter of the management's concern and a determinant 
of their operationalisation by the management in nearly $70 \%$ of the examined companies.

The surveyed entrepreneurs consciously refrain from protecting their intellectual property (inventions and technology). As reasons for their lack of interest in patents and other forms of protection of their inventions, the parties concerned - as shown by the survey - usually give excessive variability of the contemporary technology (in a few years, a given product or technology that can be patented will be outdated), time-consumption of the patent process and complicated procedures, costs, as well as the impossibility to enforce their rights, especially in the ICT industry (only $4 \%$ of the examined companies from the ICT sector indicate existence of effective mechanisms of intellectual property protection). In general, the low level of awareness of the intellectual property protection issues in the Polish business, particularly in the SME sector, as well as the conviction that the long-term, complicated and expensive procedure, and finally the patent itself, has negligible impact on the market in practice, result in resignation from the application of the patenting strategy as a tool of market competition.

Implicit (non-institutional) strategy of intellectual property protection is harder to implement in practice due to lack of protection instruments defined in normative terms. This strategy is based on copyright and the formula of non-disclosure (confidentiality) of information about the new solution, at least until the patent protection becomes effective. Implicit intellectual property protection tools may include agreements for transfer of know-how, non-disclosure agreements (NDA), trade secrets.

The choice of the implicit strategy, namely protection of intellectual assets on the basis of know-how, is usually made by organisations that do not want to disclose their solution. Know-how is not only a trade secret, constituting a unique recipe or technology, but also covers procedures, regulations, action strategies, recipes, databases (including customer bases), methods of data archiving, etc.

There are organisations or their separated parts, e.g. research and development centres in large concerns, which conduct research, solve technical problems, but the entire intellectual creation process is covered by a secret, and the research results are also classified. If competition monitoring confirms that research is carried out in the area that is already being explored by the research team working within the organisation, the management may decide to reveal the 
confidential solutions and submit the invention for patenting. This way, the organisation not only thwarts the efforts of the competitor, but also increases its own competitive and technological advantage.

The transition from confidential know-how to disclosure of the invention in order to obtain patent protection is thus a result of a strategic economic decision. However, as long as the technical knowledge is kept strictly confidential, such "classified know-how" is not subject to market operations, but it may have market potential or help the organisation earn profit. This is confirmed by two extremely different examples of technological knowledge management. IBM gained a huge market advantage through disclosure of know-how related to personal computer architecture without applying for any legal protection of its own technology. The dynamic spread of this one technology in practice caused it to determine the binding standard of PCs, the exclusive beneficiary of which was and still is IBM. On the opposite end of the spectrum is the strategy of the Coca-Cola concern, which has never disclosed the recipe for its world-famous beverage.

Know-how present on the market must be valuated, therefore the intellectual assets - information forming the entire know-how package must be identified, namely described in a way enabling the buyer to verify the confidentiality and significance of information. Know-how understood in this way may cover technical knowledge, e.g. as a supplement of knowledge included in the patent (know-how on the manufacturing technology may be offered for the license for a patented drug). It may also be non-technical knowledge, e.g. business knowledge (a list of connections with companies operating on the local market, a report on employment limitations after restructuring of the company).

The discussed form of intellectual assets protection is designed based on the absolute requirement of confidentiality of intellectual property. However, the binding clauses, non-disclosure agreements, outsourcing contracts, and monitoring of the competition's activities prevent losing of full control over the flow of information concerning the unique intellectual property. The trade secret may be violated by disloyal employees. Furthermore, there is also a risk that the competition may develop an identical solution and legally submit it in the patent office. The threats mentioned above do not depreciate the benefits of strategic activities in the scope of know-how. This protection does not require submission to the patent office and does 
not require disclosure. In addition, it is characterised by lack of time and territorial constraints of the protection and lack of costs of its obtaining and maintenance. Among the studied companies, only $10 \%$ knew of and applied this kind of intellectual property protection.

The situation is slightly better in the case of the strategy in-between the explicit and implicit strategies of intellectual property protection, namely the strategy of building the brand and trademark. The new solution is kept confidential, whereas new trademarks are introduced to the market in order to build competitive advantage on the basis of the image of the technology, product, their quality and innovation. Among the studied companies, only 5\% acknowledged for the strategically important building business model, of leaning on the facilities of license.

A strategic action with regard to protection of intellectual property is its sharing, covering many different forms and tools, among others, sale of own intellectual assets and acquisition of external assets. The implementation instruments of this strategy include: purchase, sale of licenses and combination of intellectual assets. The organisation can build its intellectual property on the basis of its own laboratory, human and financial resources. Then, it can commercialise intellectual property through sale of rights or by contribution of knowledge to the sold technologies or new products. In the strategies of sale or purchase of intellectual assets, the main role is played by such tools as contracts of sale and license agreements.

The contract of sale is a universal tool, since, on the one hand, it allows for purchase of the intellectual assets necessary for the organisation, while on the other hand, it is an instrument allowing sale of unnecessary (due to the adopted objective, competitive advantage and further development of the organisation) intellectual assets. In practice, this contract allows the organisation to supplement and enrich the possessed intellectual assets with new resources, and sometimes it is a form of optimisation and disposal of inefficient or excess resources.

In turn, the license agreement is a tool of transfer of intellectual property, both when the organisation shares its intellectual property, as well as when it wants to acquire intellectual property in technology or its components. Acquisition of intellectual property and use of solutions already existing on the market is sometimes more beneficial than conducting own works and research on a new product. In such a case, it is possible by obtaining licenses authorising to use protected solutions in exchange for a suitable remuneration. Licensing has many 
advantages. It can ensure effective return on investment in development and research by entering new markets, to which the owner of the intellectual property would not otherwise have access; creation of new relations leading to cooperation in the scope of development and research; or provision of measures of control and direct access to development of new technologies.

One strategic action also involves sharing of intellectual assets, which covers many different forms and tools, among others, licenses, leasing, crowdsourcing, crowdfunding, crowdcasting, and franchising. The described strategic action is frequently used in the processes of creating a strategic alliance that permits the cooperation of partners on the basis of intellectual assets remaining in exclusive ownership of one of the participants of the created strategic alliance.

\section{SUMMARY}

In the contemporary economy, intangible regulatory assets (intellectual property) are one of the pillars of the organisation's competitiveness. In order to fully utilise the value of these assets, organisations should think about them in strategic terms (Baruk, 2006). When creating the general strategy of action, organisations should take account of these assets in their strategic plans and try to integrate them with other important assets and activities (Bak \& Kulawczuk, 2009). Strategic thinking means thinking about the future; in the case of assets in the form of intellectual property it may take on different directions. It may apply to creation of these assets, their acquisition or maintenance and protection (Burgelman et al., 2009). Protection of these assets involves selection of a specific strategy, which may guarantee acquisition and maintenance of competitive advantage.

Despite the different needs and different approaches to the problem of intellectual property protection, the actions taken in this regard must be consistent with the market conduct strategy of the organisation. The strategic need for protection of intellectual property assets constitutes a component of the intellectual property management process, in which intellectual assets are transformed into financial results. The awareness and practice of strategic thinking, namely planning, building scenarios of the environment and preparing various options of the use and protection of the intellectual property assets potential, 
not only creates development opportunities for the organisation, but also opportunities for development of new market space for products prepared on the basis of these assets. The results of the study conducted in the SME sector of the Lower Silesia, discussed in the article, expressly indicate insufficient knowledge and understanding of the strategic approach to intellectual property management among Polish companies.

\section{REFERENCES}

Allen, K. (2010). Entrepreneurship for scientists and engineers. Upper Saddle River, New Jersey: Prentice Hall.

Bąk, M. \& Kulawczuk, P. (eds.) (2009). Intellectual and Technological Entrepreneurship of the 21st Century. Warsaw: Publishing House of the National Chamber of Commerce.

Bainbridge, D. (2009). Intellectual Property. Harlow: Pearson Education Limited. Barrett, M. (2008). Intellectual Property. New York: Aspen Publishers.

Baruk, J. (2006). Knowledge Management and Innovation. Toruń: Adam Marszałek Publishing House.

Blair, R.D. \& Cotter, T.F. (2005). Intellectual Property: Economic and Legal Dimensions of Rights and Remedies. New York: Cambridge University Press.

Burgelman, R.A., Christensen, C.M. \& Wheelwright, S.C. (2009). Strategic Management of Technology and Innovation. Boston-Toronto: McGrow-Hill.

Dereń, A.M. (2015a). Utilization of institutional forms of protection of intellectual property In enterprise - outline of issues. In: M. Dąbrowska \& R. Gnitecka (eds.), Management of Modern Organization: Selected Issues. Legnica: Publishing House of the Witelon State University of Applied Sciences in Legnica.

Dereń, A.M. (2015b). Knowledge of the management and protection of intellectual property in SMEs in Lower Silesia. Study report. Report from PRE series. In: Reports of the Faculty of Computer Science and Management of the Wrocław University of Technology, PRE Series. Wroclaw, No. 29.

Głuszek, E. (2004). Management of Intangible Assets of an Enterprise. Wrocław: Publishing House of the Oskar Lange Academy of Economics.

Gwarda-Gruszczyńska, E. (2010). Enterprise strategies and intellectual property protection. In: M.D. Trzmielak (ed.), Commercialization of Knowledge and Technology and Intellectual Property, Łódź: Center for Technology Transfer, University of Lodz. 
Hall, R. (1992). The strategic analysis of intangible resources. Strategic Management Journal, 13.

May, Ch. (2007). The World Intellectual Property Organization: Resurgence and the Development. New York: Routledge.

Mikuła, B., Pietruszka-Ortyl, A. \& Potocki, A. (2002). Business Management of the 21st Century. Selected Concepts and Methods. Warsaw: Publishing House Difin.

Obłój, K. (2001). Organizational Strategy. Warsaw: Polish Economic Publishing House.

Parr, R.L. \& Smith, G.V. (2010). Intellectual Property: Valuation, Exploitation and Infringement Damages. Cumulative Supplement. Hoboken, New Jersey: John Wiley \& Sons Inc.

Pierścionek, Z. (1996). Business Development Strategies. Warsaw: Polish Scientific Publishers.

Sitek, E. (1997). Development strategy in termsof resource theory of the company. Journal Economist, 5, 6.

Stańczyk-Hugiet, E.I. (2013). Strategic Dynamics in Evolutionary Concept. Wrocław: Publishing House of the Wrocław University of Economics.

Toffler, A. \& Toffler H. (1999). Construction of a New Civilization. Third Wave Policy. Poznań: Publishing House Profit and S-ka.

Toffler A. \& Toffler H. (1997). War and Anti-war. How to Survive on the Threshold of the 21st Century. Warsaw: Polish Economic Publishing House.

Trzmielak, M.D. (ed.) (2010). Commercialization of Knowledge and Technology and Intellectual Property. Łódź: Center for Technology Transfer, University of Lodz.

Trzmielak, D. \& Byczko, Sz. (2010). Management of Intellectual Property in the Enterprise and at the University. Gdańsk: Gdańsk Institute for Market Economics.

Woś, A. (1995). Economics of Renewable Natural Resources. Warsaw: Polish Scientific Pulishers. 


\title{
STRATEGIE ZABEZPIECZANIA WKASNOŚCI INTELEKTUALNEJ JAKO NIEMATERIALNEGO ZASOBU REGULACYJNEGO ORGANIZACJI
}

\begin{abstract}
Abstrakt
Tło badań. Jedną z cech zasobowych własności intelektualnej jest zdolność do ochrony. W procesie zarządzania własnością intelektualną cecha ta determinuje formułowanie i realizację strategii ochrony tych zasobów.

Cele badań. W artykule przedstawiono szczególny rodzaj niematerialnego zasobu regulacyjnego, jakim jest własność intelektualna w organizacji. Przyjmując, że strategia ochrony własności intelektualnej musi być uporządkowana celom organizacji, omówiono strategię jawną (instytucjonalna) ochrony własności intelektualnej, strategię niejawną (pozainstytucjonalna) oraz strategię opartą na sprzedaży własnych zasobów intelektualnych i/lub pozyskaniu zasobów zewnętrznych.
\end{abstract}

Metodologia. Wybrane i omówione strategie, które w pełni ilustrują zdolność do ochrony własności zasobów własności intelektualnej, były przedmiotem badań prowadzonych w grupie polskich przedsiębiorstw z regionu Dolnego Śląska.

Kluczowe wnioski. Przeprowadzona analiza pozwoliła na wyróżnienie dwóch typów strategii zabezpieczania własności intelektualnej: strategie instytucjonalne (patent, prawa ochronne, itp.) i nieinstytucjonalne (know-how, tajemnica przedsiębiorstwa). Zdecydowana większość badanych przedsiębiorców stosuje instytucjonalne strategie ochrony własności intelektualnej mimo złożonych procedur formalnych i znacznych kosztów.

Słowa kluczowe: organizacja, zasoby, własność intelektualna, ochrona. 